\title{
Observation of Bearing Capacity of Land-based on Soil Engineering Properties in Semarang Central Java Indonesia
}

\author{
Pribadi Agung Wahyudi ${ }^{1}$, Purwanto ${ }^{2}$, Thomas Triadi Putranto ${ }^{3}$ \\ \{ahliteknik@yahoo.co.id ${ }^{1}$, p.purwanto@gmail.com ${ }^{2}$, putranto@ft.undip.ac.id ${ }^{3}$ \} \\ Universitas Diponegoro, Indonesia ${ }^{1,2,3}$
}

\begin{abstract}
The stability of bearing capacity of land is influenced by the conditions and characteristics of the resources in the space/land/region, called the supply capacity. The capacity to provide in terms of bearing capacity of land for the allocation of space utilization is determined by the stability of the land mass that forms the land, namely soil engineering properties. The real phenomenon that occurs due to the failure of the bearing capacity of land is land subsidence, both due to engineering and natural. Frequently encountered phenomena indicating failure of land bearing capacity: land subsidence, failure of infrastructure buildings. This is what underlies this research. The study was conducted in the city of Semarang which is geographically located between $6^{\circ} 50^{\prime}-7^{\circ} 10^{\prime}$ South Latitude and $109^{\circ} 50^{\prime}-110^{\circ} 35^{\prime}$ East Longitude located on the coast of the Java island. Research by drilling, sondir at the test points spread in the city of Semarang. From this study obtained parameters of soil engineering properties that determine the stability of the bearing capacity of land: very soft to soft/very loose has a bearing capacity of land $=<0.904 \mathrm{~kg} / \mathrm{cm}^{2}$, rather soft $/$ loose resistance has a bearing capacity of land $=0.904-2.035$ $\mathrm{kg} / \mathrm{cm}^{2}$, rather hard to hard/rather dense has a bearing capacity of land $=2.035$ $5.880 \mathrm{~kg} / \mathrm{cm}^{2}$, very hard $/$ dense to very dense has a bearing capacity of land $=5.880->$ $9.93 \mathrm{~kg} / \mathrm{cm}^{2}$.
\end{abstract}

Keywords: Bearing Capacity of Land, Conus Resistance (qc), Soil Engineering Properties.

\section{Introduction}

Law of the Republic of Indonesia Number 32 of 2009 [1] concerning Environmental Protection and Management, and in Regulation of the Minister of Environment Number 17 of 2009 [2] concerning Guidelines for Determination of Bearing Capacity for the Environment in Regional Spatial Planning, that stability of land bearing capacity is a stability of land capability, which is a characteristic of land including land characteristics, topography, drainage, and other environmental conditions to support for life/activities on a stretch of land. Bearing capacity of land is a capacity of the natural environment and the resources for determine a bearing capacity of the environment. Capacity of natural environment and resources is influenced by conditions and characteristics of the resources that exist on land.

The ability of land/bearing capacity for land use allocation is a major factor in determining the carrying capacity of environment, considering the comparison between land availability in demand for water availability in demand does not materialize if bearing 
capacity of land is unstable. Bearing capacity/capacity of land for space utilization so far is based on calculation of land capability for agriculture and from physical aspects of land in accordance with Minister of Environment Regulation Number 17 of 2009, concerning Guidelines for Determination of Bearing Capacity for the Environment in Regional Spatial Planning. In fact, there are important factors that are not yet included in the Guidelines for Determination of Environmental Carrying Capacity in Regional Spatial Planning, related to land capability/bearing capacity in terms of aspects of soil engineering properties, which is characteristics of the land mass forming land overlays.

Bearing capacity as a land mass that forms a stretch of land not only includes the ability of land for agriculture or physical aspects of land, but more to technical nature of subsurface soil mass. The phenomenon of environmental damage that occurs due to characteristic nature of soil engineering is land subsidence.

a)

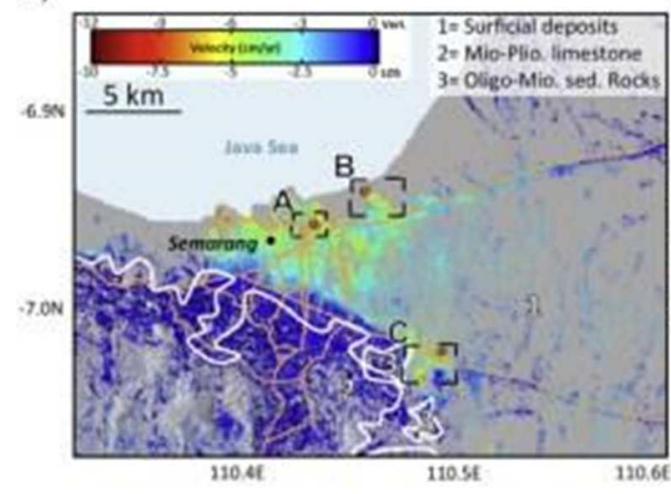

b)

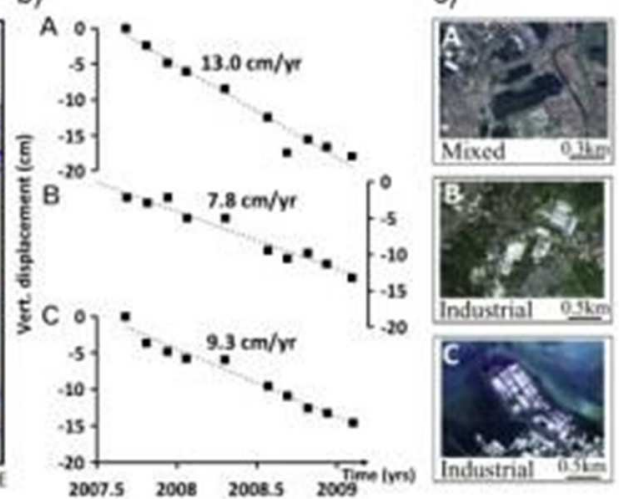

Fig. 1. Land subsidence rate in the city of Semarang-Demak [3][4].

Direct changes to physical and/or biological characteristics due to land subsidence, cause stability of bearing capacity as the physical environment decreases. Changes in the environment due to tidal inundation (Rob) as consequences from land subsidence, causing disruption of homeostasis conditions to be one cause of environmental degradation [5].

Development of Semarang city area is absolutely necessary areas that are ready to be built city infrastructure and facilities. This tendency has led to continued land engineering efforts and vulnerable areas for construction into areas that are ready to be built complete with the infrastructure (Local Government Regulation Number 14 of 2011 [6] concerning Semarang City Spatial Planning 2011-2031).

In reality, there are often phenomena that indicate planning failure: subsidence in the relocation area of settlements, submergence of artificial areas due to land subsidence, due to the lack of initial information about bearing capacity of land based on soil engineering properties. This research will answer for above problems related to how to measure and analyze the parameter's value of soil engineering properties that determine bearing capacity of land in the city of Semarang. According to availability of soil engineering properties information in relation to bearing capacity of land in the city of Semarang, it can be an instrument for evaluating spatial use so that land use is compatible with bearing capacity of land. 


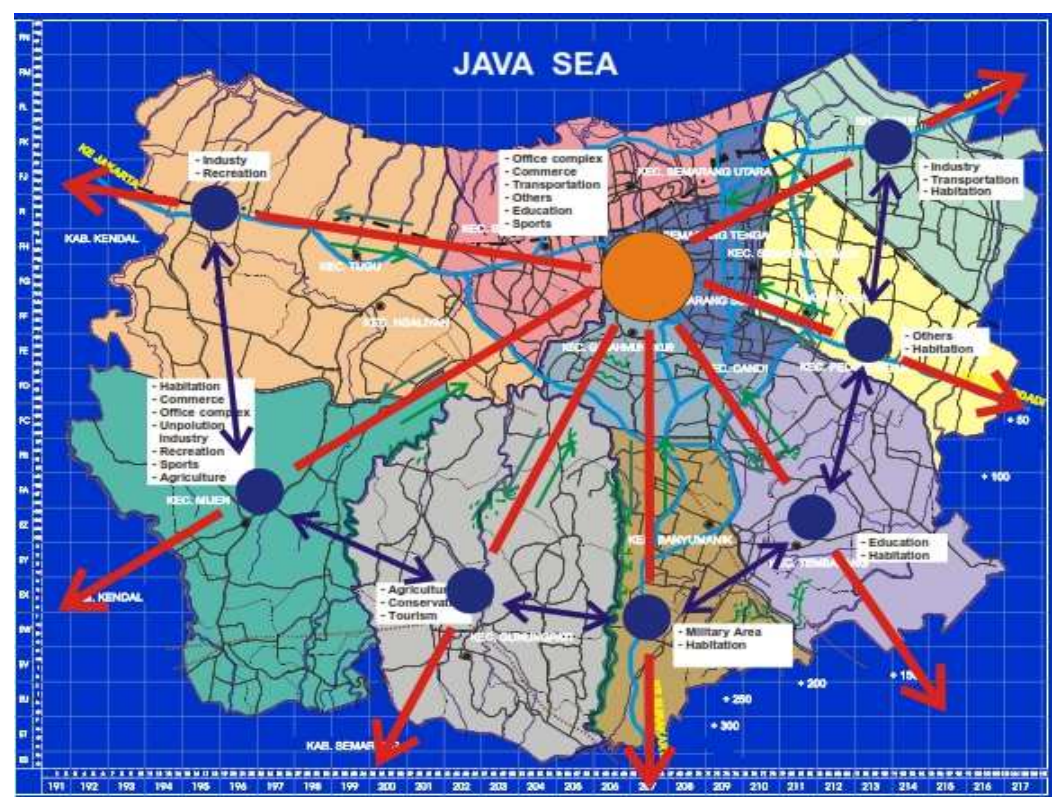

Fig. 2. Division of Semarang City area and Its Duties [6].

\section{Research Methods}

\subsection{Place and time of research}

The study was conducted in the city of Semarang which is geographically located between $6^{\circ} 50^{\prime}-7^{\circ} 10^{\prime}$ South Latitude and $109^{\circ} 50^{\prime}-110^{\circ} 35^{\prime}$ East Longitude located on the coast of the Java island with North boundary of Java Sea, South boundary of Semarang Regency Area, West boundary of Kendal Regency Area, East boundary of Demak Regency Area, with an area of $=373.70 \mathrm{~km}^{2}$ [7]. The sampling points are carried out randomly which are spread out in the range of Semarang City area.

\subsection{Research Materials}

The population in this study is the geological structure / subsurface soil systems of Semarang City with various characters. The sampling points are carried out randomly which are spread out in the range of Semarang City area. The city of Semarang is a coastal area in the north which is dominated by silt clay. While in the south is a hilly area dominated by silt and sand soils, even some places have rocks [8] [9]. 


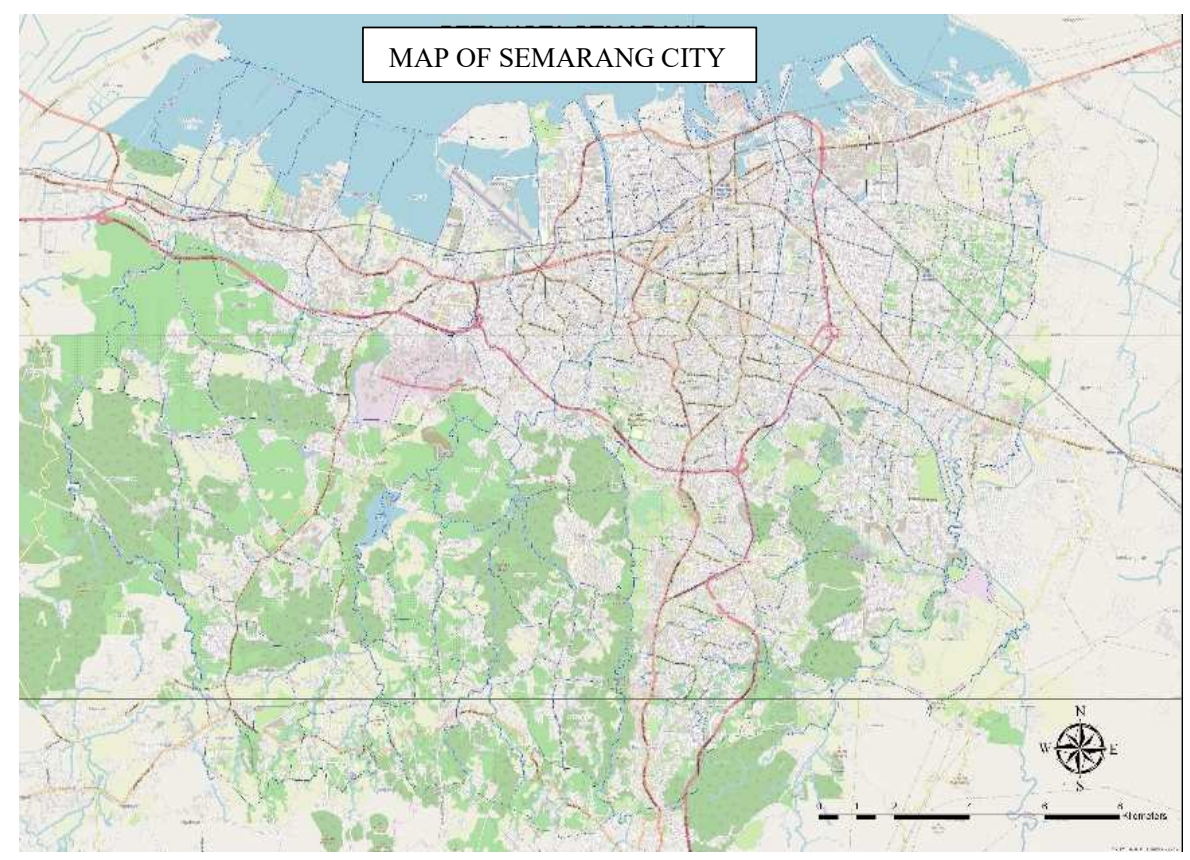

Fig. 3. Semarang City Research Area.

\subsection{Data Collection}

Data collection is carried out from various sources and or various ways, which is:

a) Secondary data collection from the results of literature review on previous research and geological map of the city of Semarang [10].

b) Field research

Penetration testing using Dutch Cone Penetrometer or sondir equipment is classified as static penetration testing. Working method according to ASTM D-3441 [11] from this equipment is to enter into soil of sondir tip (conus) by pressing, then the force used to press the conus into the ground is measured by a pressure gauge (manometer-gauge) which will show a value of cone resistance and fixed resistance in $\mathrm{kg} / \mathrm{cm}^{2}$. Measurements of the pressure force are carried out at intervals of $20 \mathrm{~cm}$ and carried out to a depth of $30 \mathrm{~m}(2.5$ tons capacity) or hard soil (end resistance value $(\mathrm{qc})=>250.00 \mathrm{~kg} / \mathrm{cm}^{2}$ ). The value of cone-sondir resistance read on manometer shows the relative density of soil layers founded, an indicator of Oil bearing capacity [12].

\subsection{Processing and data analysis}

After preparing the equipment and permits needed in this study, this research was carried out in stages:

a) Sondiring at a predetermined point. Data that can be obtained directly in this activity are cone resistance (qc), friction ratio (fr) in situ.

b) Analyzing data obtained from the field:

- From visual observations and measurements can be made sondir graph.

- Furthermore, from the sondir graph we can find out a soil engineering property. 
- Calculate the bearing capacity stability indicator of land at depth under study $(0 \mathrm{~m}$ to $8.00 \mathrm{~m}$ ) by calculating bearing capacity of permit against the load

- Presenting the correlation of land bearing capacity indicators from value of cone resistance with bearing capacity of the land permits to the load in a graph.

- Zoning of bearing capacity indicator parameters examined on the topographic map of Semarang City.

\section{Results and Discussion}

\subsection{Bearing Capacity of Land (BCL)}

Definition of the land according to regulation of minister of environment number 17 of 2009 concerning guidelines for determining bearing capacity of the environment in spatial planning is a land area whose characteristics summarize all signs concerning biosphere, atmosphere, soil, geology, relief, hydrology, plant and animal populations, as well as results of past and present human activities that are stable or recycled [13].

Land is a structural manifestation of planned spatial use, which includes location patterns, distribution of settlements, workplaces (trade and offices), industry, recreation areas, land use patterns.

According to the Republic of Indonesia Law number 26 of 2007 [14] concerning spatial planning article 19, article 22, article 25, and according to Government Regulation number 15 of 2010 concerning Implementation of Spatial Planning article 25, article 27, article 32, article 35, Provincial Governments and Regency / Municipal Governments must compile regional spatial plans according to level by taking into account environmental bearing capacity.

Determination of environmental bearing capacity is measured by knowing capacity of the natural environment and resources to support human life in space for existence of his life. Amount of capacity mentioned above is influenced by conditions and characteristics of resources in existing space:

- Land capability for allocation of land use;

- Comparison between land availability and needs;

- Comparison between water availability and needs;

The ability of land bearing capacity of land that reviewed in this paper as a major factor in determining bearing capacity of the environment, because of 2 other factors i.e. the comparison between availability and needs of land and water will never be surprised if bearing capacity of land is unstable. The phenomenon is that the land / region due to natural processes and human engineering have subsidence/decline, causing the failure of bearing capacity/ability of land and environmental damage. Which of these phenomena is more related to the nature of subsurface mass engineering techniques?

Bearing capacity of the land is defined as ability of the land to withstand the workload without collapse due to shifting. By stressing the stress in soil increases, initially the soil solidifies due to dissipation of pore pressure. If the load increases, cracks will arise in soil until it reaches a point when strength of the soil reaches limit. If the power limit is exceeded, soil will break and burden will be pushed to side. The event is said that balance of land or bearing capacity, that is, bearing capacity of the balance is exceeded. Compacting of the soil causes construction to fall (deformation). If the load gets bigger the construction suddenly drops a lot and it is quickly said that bearing capacity of the surge is exceeded. So the stability 
of soil can be achieved if soil balance limit (bearing capacity of the soil) and the balance limit of displacement (bearing capacity of displacement) are not exceeded.

The balance limit depends on shear strength of the soil. Shear strength of the soil is used to calculate the soil balance limit (bearing capacity as measured by conditional resistance of qc sondir in $\mathrm{kg} / \mathrm{cm}^{2}$ ) which can be used as an indication whether failure of the soil is caused due to exceeding the bearing capacity or other causes [15].

\subsection{Failure Implications of Land Bearing Capacity on the Environment}

Land/soil as a physical environment where as all human activities in meeting the needs of life requires space, so the availability of stable land (not sink) is very influential on human activity. Implication of failure of land bearing capacity (subsidence) on the environment can be explained as follows:

- Land subsidence continues when voltage changes continue to increase due to loading, causing the carrying capacity of the land to be exceeded.

- Problems occur in the city of Semarang, especially lower part of the city when subsidence continues, at certain times the land level reaches lower to the surface of the tide so that it occurs tidal.

- Direct changes to the physical and/or biological nature of nature occur, causing disruption of the natural condition of homeostasis which results in decreased carrying capacity of the environment, damage to the condition of homeostasis, one of the causes of environmental degradation.

- Environmental degradation is a direct or indirect change in physical and/or biological nature of the environment resulting in decreased environmental bearing capacity.

- Disruption to the condition of homeostasis results in the formation of new homeostasis conditions or even the destruction of homeostasis conditions so that important ecological processes and bearing capacity of life are unable to recover.

\subsection{Physical and Engineering Soil Properties}

Physical properties are indicated by parameters of water content $(\mathrm{w})$, mass volume weight $(\gamma \mathrm{b}, \gamma \mathrm{d})$, specific gravity (Gs), porosity (n), pore number (e), plasticity (LL, PL, PI, LI) and gradation passed filter \# 200. Engineering properties are indicated by parameters of free compressive strength (qu), cohesion (c), internal shear angle $\left({ }^{\circ}\right)$ (Wahyudi 1989 - 2018) and conus resistance $(\mathrm{qc})$. From these physical and engineering parameters it can be seen the classification of Semarang City subgrade. Physical properties pass 200 filters; $0.074 \mathrm{~mm}>$ $50 \%$ is classified as fine grained and less than $50 \%$ is classified as coarse grained (USCS = Casagranda 1984). The nature of fine-grained soil will be very different behavior than coarse grained soil in its stability and bearing capacity. Fine-grained soil will be largely determined by the nature of its plasticity (Atterberg), with plasticity maps can be classified as soil in Figure 4 [16]. And then relationship between plasticity index, level of plasticity and type of soil are mentioned in the Table 1. 


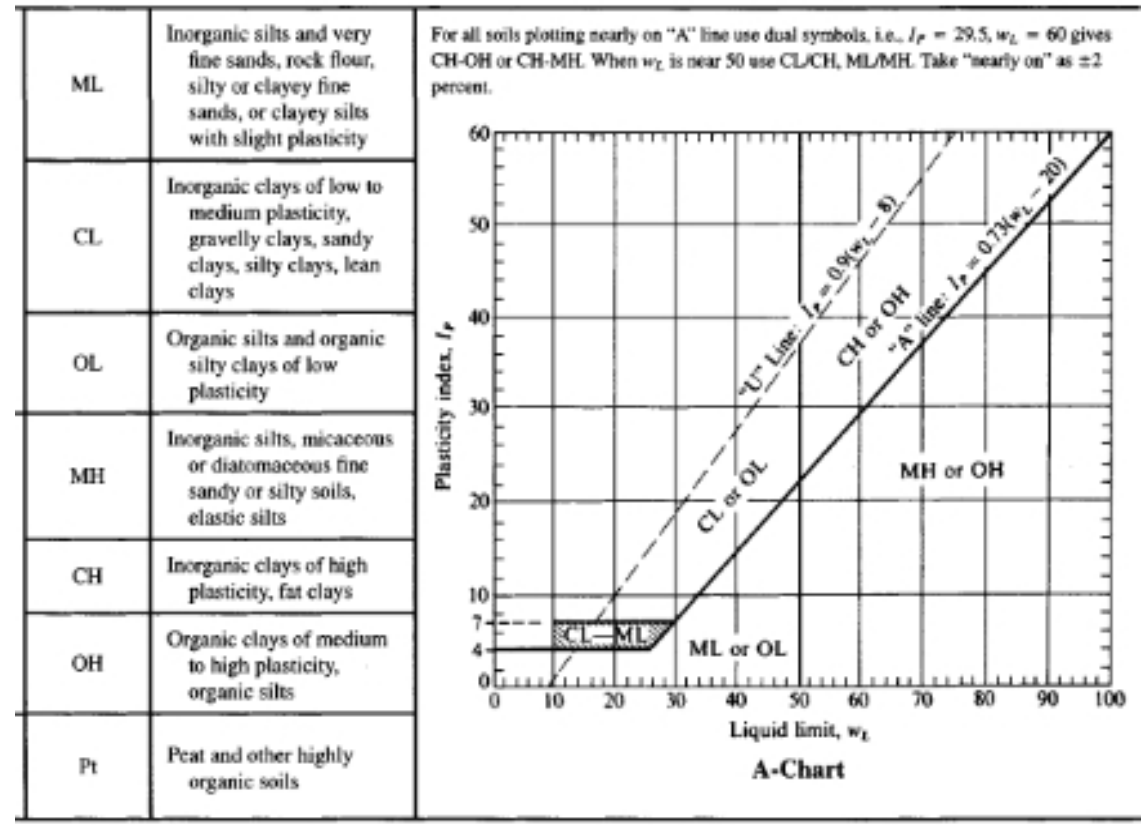

Fig. 4. Atterberg Plasticity Map (Foundation Analysis and Design, Bowles, 1986).

Table 1. Relationship between plasticity index, level of plasticity and type of soil

\begin{tabular}{ccc}
\hline PI & Plasticity Level & Soil Type \\
\hline 0 & Non Plastic & Sand \\
$0-7$ & Low & Silt \\
$7-17$ & Medium & Silty - Clay \\
$>17$ & High & Clayed - Silt \\
\multicolumn{2}{c}{ (Soil Mechanics, Jumikis - PT. MBT Bandung [17]) }
\end{tabular}

Coarse grained soil is strongly influenced by its gradations character: good gradation (even grain size), uniform gradation and poor gradation (gap grain size). Grain size is the most obvious soil characteristic, so the soil classification is first based on texture in Figure 5. 


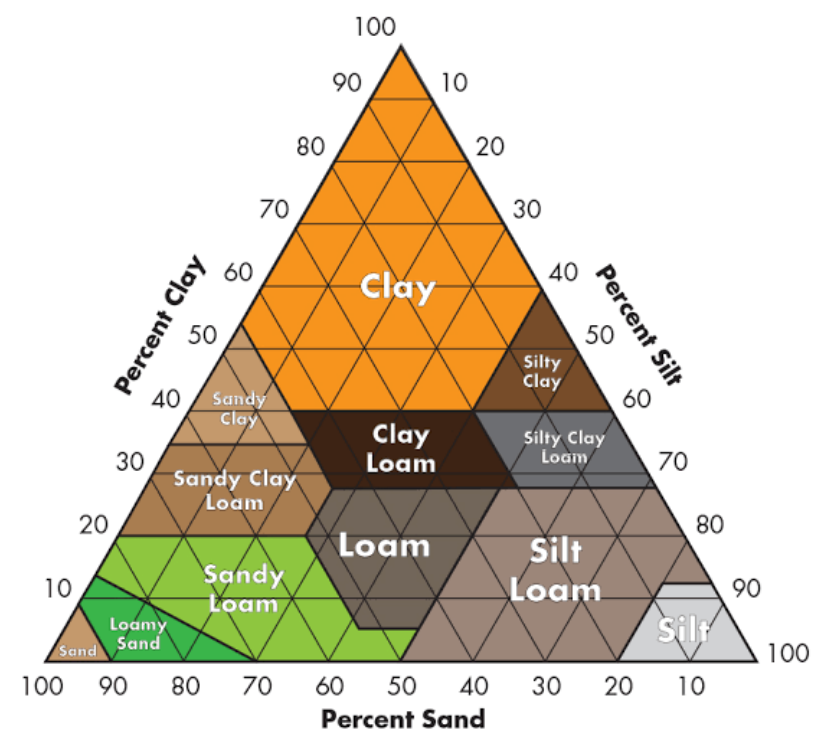

Fig. 5. Texture Classification [17].

Engineering properties parameters are qu free compressive strength (especially for fine grained) and cohesion (c) as well as internal shear angle $\left(^{\circ}\right)$ for coarse grains, and cone resistance (qc) which is an indication directly in the field without being disturbed. The relationship between coarse grained soil parameters and stability properties is presented in Table 2. For fine-grained soils there is a relationship between technical parameters and soil properties as in Table 3 .

Table 2. Relationship between coarse grained soil and engineering properties

\begin{tabular}{|c|c|c|c|c|c|c|}
\hline Density Level & Relati & ve Density & $\mathrm{f}$ & \multicolumn{3}{|c|}{ Strength $\mathrm{q}_{\mathrm{c}}\left(\mathrm{kg} / \mathrm{cm}^{2}\right)$} \\
\hline Veryloose & \multicolumn{2}{|c|}{$<0.2$} & $<30$ & \multicolumn{3}{|c|}{$<20.4$} \\
\hline loose & 0.2 & 0.4 & $30-35$ & 20.4 & - & 45.90 \\
\hline rather solid & 0.4 & 0.6 & $35-40$ & 45.9 & - & 132.60 \\
\hline solid & 0.6 & 0.8 & $40-45$ & 132.6 & - & 224.40 \\
\hline Very solid & $>$ & 0.8 & $>45$ & $>$ & & 224.40 \\
\hline
\end{tabular}

Source: Hand Book of Soil Mechanics Soil Testing [15].

Table 3. Relationship between technical parameters and fine-grained soil properties.

\begin{tabular}{|l|c|}
\hline \multicolumn{1}{|c|}{ Level Density } & Strength $\mathrm{qu}_{\mathrm{u}}\left(\mathrm{kg} / \mathrm{cm}^{2}\right)$ \\
\hline very soft & $<0.25$ \\
\hline soft & $0.25-0.5$ \\
\hline rather soft & $0.5-1.0$ \\
\hline rather hard & $1.0-2.0$ \\
\hline hard & $2.0-4.0$ \\
\hline
\end{tabular}




\begin{tabular}{|c|c|}
\hline Very hard & $4.0-8.5$ \\
\hline \multicolumn{2}{|l|}{ Source: The Penetrometer and Soil Exploration [18] }
\end{tabular}

Homogeneous physical and engineering soil propertiess will make the soil characteristics same in terms of stability and bearing capacity [16]. In this study the grouping of data based on parameters of physical and engineering properties as well as taking into account geotechnical conditions [9]. As a main indicator of technical character of cone prisoner qc, because it is result of direct field testing without being interrupted, and also physical properties of gradations $>50 \%$ and $<50 \%$ pass filter no. 200; $00.074 \mathrm{~mm}$. Indicators of other physical and engineering properties as supportive and show an analogous relationship. Criteria for physical and engineering properties that give an indication of soil properties according to Kezdi and Sanglerat, 1972 are presented in Table 4.

Table 4. Criteria for physical and engineering properties

\begin{tabular}{cccccc}
\hline \multicolumn{5}{c}{ Parameters (quantitative) } & Soil Characteristic (Qualitative) \\
\hline $\begin{array}{c}\text { Relative } \\
\text { Density }\end{array}$ & Phi & $\begin{array}{c}\text { Strength qc } \\
(\mathrm{kg} / \mathrm{cm} 2)\end{array}$ & $\begin{array}{c}\text { Qu } \\
(\mathrm{kg} / \mathrm{cm} 2)\end{array}$ & $\begin{array}{c}\text { Fine-grain } \\
>50 \% \text { pass \# } 0.074\end{array}$ & $\begin{array}{c}\text { Coarse-grain }<50 \% \\
\text { pass \# 0.074 }\end{array}$ \\
\hline$<0.2$ & $<30$ & $<20.4$ & $<0,5$ & Very soft to soft & Very loose \\
\hline $0.2-0.4$ & $30-35$ & $20.4-45.9$ & $0,5-1,0$ & Rather soft & loose \\
\hline $0.4-0.6$ & $35-40$ & $45.9-132.6$ & $1,0-4,0$ & Rather hard to hard & Rather solid \\
\hline $0.6->0.8$ & $\begin{array}{c}40- \\
>45\end{array}$ & $\begin{array}{r}132.6- \\
>224.4\end{array}$ & $4,0-8,5$ & Very hard & Solid to very solid \\
\hline \multicolumn{7}{c}{ Source: Kezdi-Sanglerat [18]. }
\end{tabular}

\subsection{Result of Research}

Research location for data collection in the Semarang City area about physical and engineering properties of soil amounted to 179 sondir points and 164 borer points can be seen in Figure 4, i.e. Data of Soil Research Results in Semarang City which shows the distribution of locations of Sondir and Boring field test points, at depths reaching- 8.00 meters below ground level [10].

With this grouping a conclusion can be drawn from criteria for characteristics of subgrade reaching a depth of -0.00 to $-8.00 \mathrm{~m}$ in accordance with Kezdi-Sanglerat criteria. At the same criteria points are grouped side by side and a careful visual observation of field with geotechnical map reference by taking into account geological features with the Environmental Geology unit notation: (Geological Map of Geology Directorate of Environmental Management for Magelang-Semarang sheet). Grouping of test points with the same soil characteristics is plotted on topographic map of Semarang City area. Plotting that have an indication of characteristis for homogeneous in classification that has been determined refers to Kezdi and Sanglerat [12][19][20][21]. The classification is very soft to soft, rather soft, rather hard to hard and very hard or very loose, loose, rather dense and dense to very dense. 
Ploting the set of points showing indications of soil properties with the classification that has been determined will be traced to the classification dividing line by paying close attention to visual observations in the field and geological map reference, which will become zoning boundaries of Semarang City region as shown in Figure 5. Correlating Interpretation of Soil Engineering Properties and Value of Land Bearing Capacity in Semarang City presented in Table 6, where is according to Meyerhof (1956) and Bowles (1996), based on the Terzaghi and Peck curves of (1943) Permitted bearing capacity of land $=(\mathrm{qc} / 30) \mathrm{Kd}(\mathrm{kg} / \mathrm{cm} 2)$ and $\mathrm{Kd}=1+0,33(\mathrm{Df} / \mathrm{B})<1,33[16]$.

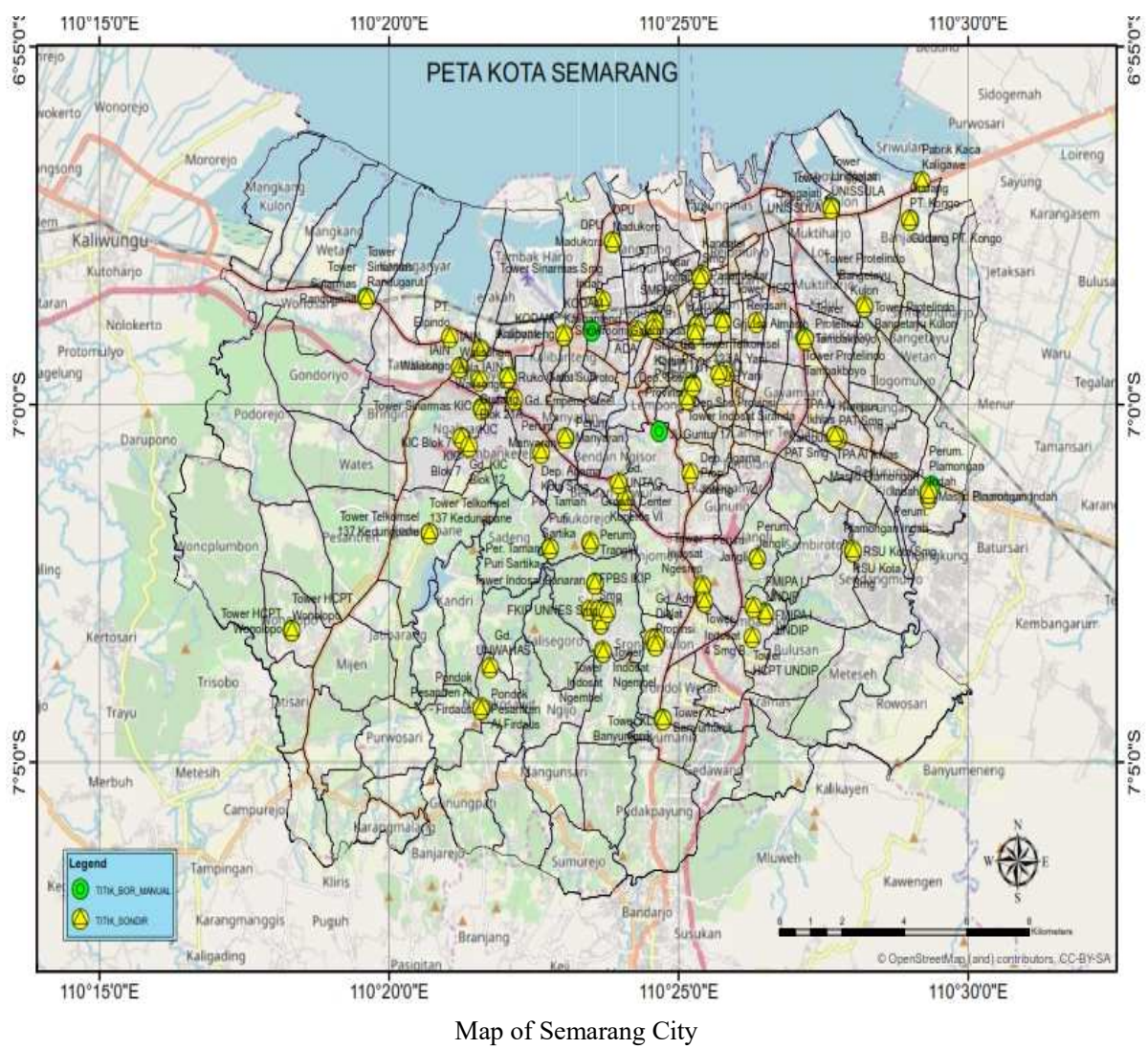

Fig. 4. Sondir and Borer points. 


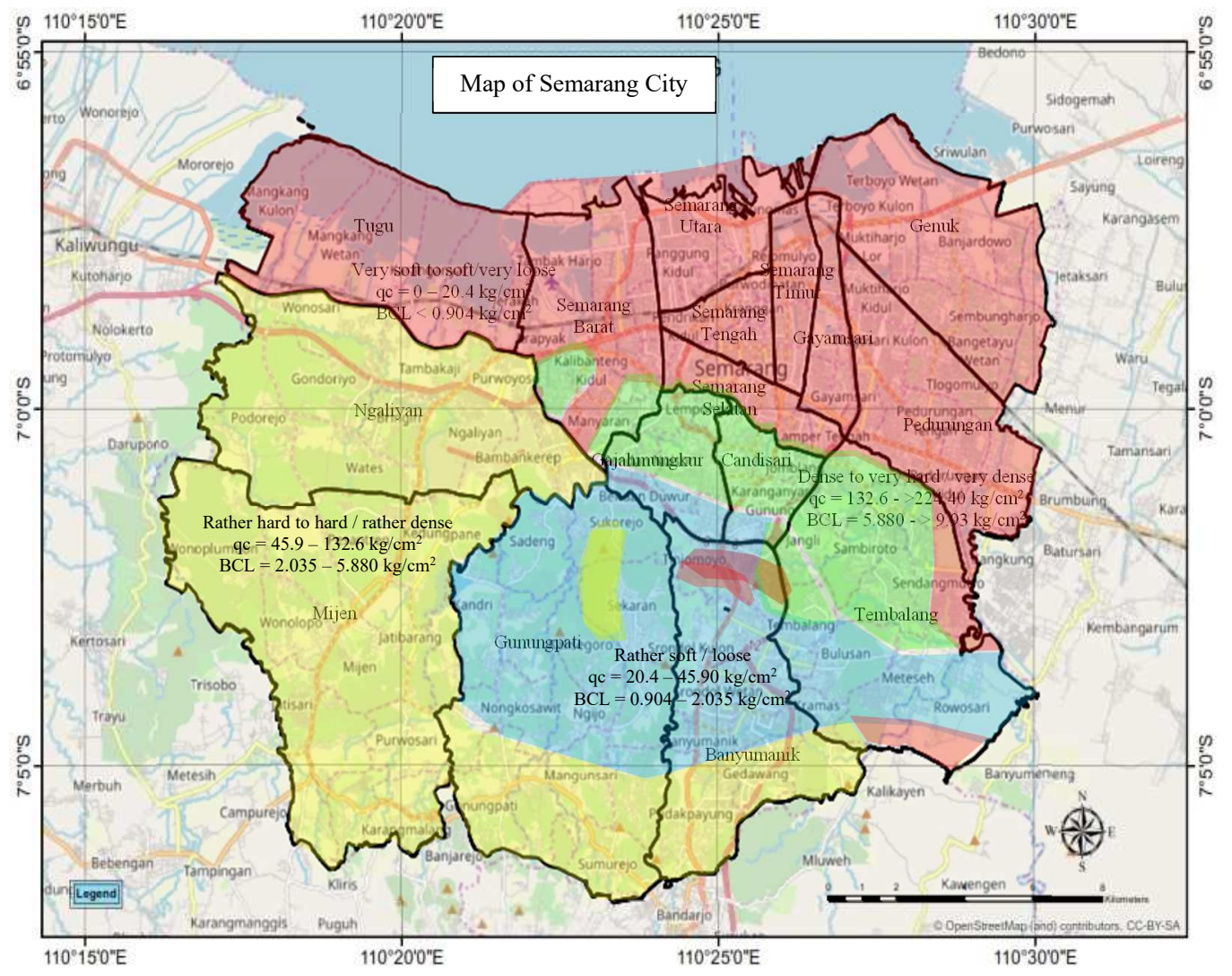

Fig. 5. Zoning Map of Soil Classification for Semarang City.

Table 5. Correlating Interpretation of Soil Engineering Properties and Value of Land Bearing Capacity

\begin{tabular}{|c|c|c|c|c|c|c|}
\hline \multirow[t]{2}{*}{ District } & \multirow[t]{2}{*}{ Sondir Points } & \multirow[t]{2}{*}{ Description } & \multicolumn{2}{|c|}{$\mathrm{qc}\left(\mathrm{kg} / \mathrm{cm}^{2}\right)$} & \multicolumn{2}{|c|}{$\begin{array}{l}\text { Bearing Capacity of Land } \\
\left(\mathrm{kg} / \mathrm{cm}^{2}\right)\end{array}$} \\
\hline & & & $\min$ & $\max$ & $\min$ & $\max$ \\
\hline Gayamsari & 3 & Silt-Clay & 8 & 10 & 0,355 & 0,443 \\
\hline Genuk & 8 & Silt - Clay & 2 & 10 & 0,089 & 0,443 \\
\hline Pedurungan & 6 & Silt - Clay & 4 & 20 & 0,177 & 0,887 \\
\hline Semarang Tengah & 11 & Silt - Clay & 2 & 12 & 0,089 & 0,532 \\
\hline Semarang Timur & 10 & Silt - Clay & 1 & 20 & 0,044 & 0,887 \\
\hline Semarang Utara & 11 & Silt - Clay & 0 & 3 & 0 & 0,133 \\
\hline Banyumanik & 23 & Silt - Sand - Clay & 5 & 240 & 0,222 & 10.640 \\
\hline Candisari & 7 & Sand - Silt - Gravel & 22 & 250 & 0,975 & 11.083 \\
\hline Gajahmungkur & 19 & Silt - Sand - Gravel & 28 & 250 & 1,241 & 11,083 \\
\hline Semarang Selatan & 9 & Silt - Clay & 2 & 10 & 0,089 & 0,443 \\
\hline Tembalang & 17 & Silt - Sand-Clay & 4 & 240 & 0,177 & 10,640 \\
\hline Gunungpati & 14 & Silt - Sand - Clay & 22 & 120 & 0,975 & 5,320 \\
\hline Mijen & 2 & Sand - Gravel - Silt & 80 & 100 & 3,547 & 4.433 \\
\hline Ngaliyan & 3 & Sand - Gravel - Silt & 75 & 100 & 3,325 & 4.433 \\
\hline Semarang Barat & 34 & Silt - Clay - Sand & 2 & 250 & 0,089 & 11.083 \\
\hline Tugu & 2 & Silt - Clay & 2 & 4 & 0,089 & 0,177 \\
\hline Sum & 179 & & & & & \\
\hline
\end{tabular}


From results of calculation for value of cone resistance (qc) and bearing capacity of the land regressed obtained graph correlation parameters of soil engineering properties for land bearing capacity in Semarang City as follow figure 6 .

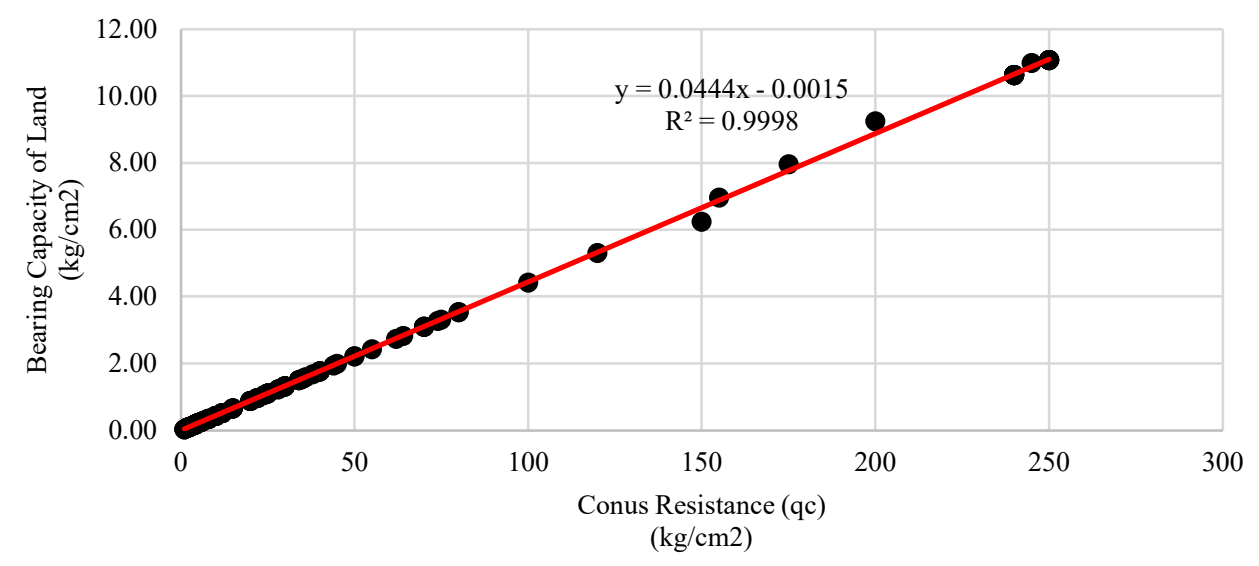

Fig. 6. Correlation between conus resistance (qc) and bearing capacity of land

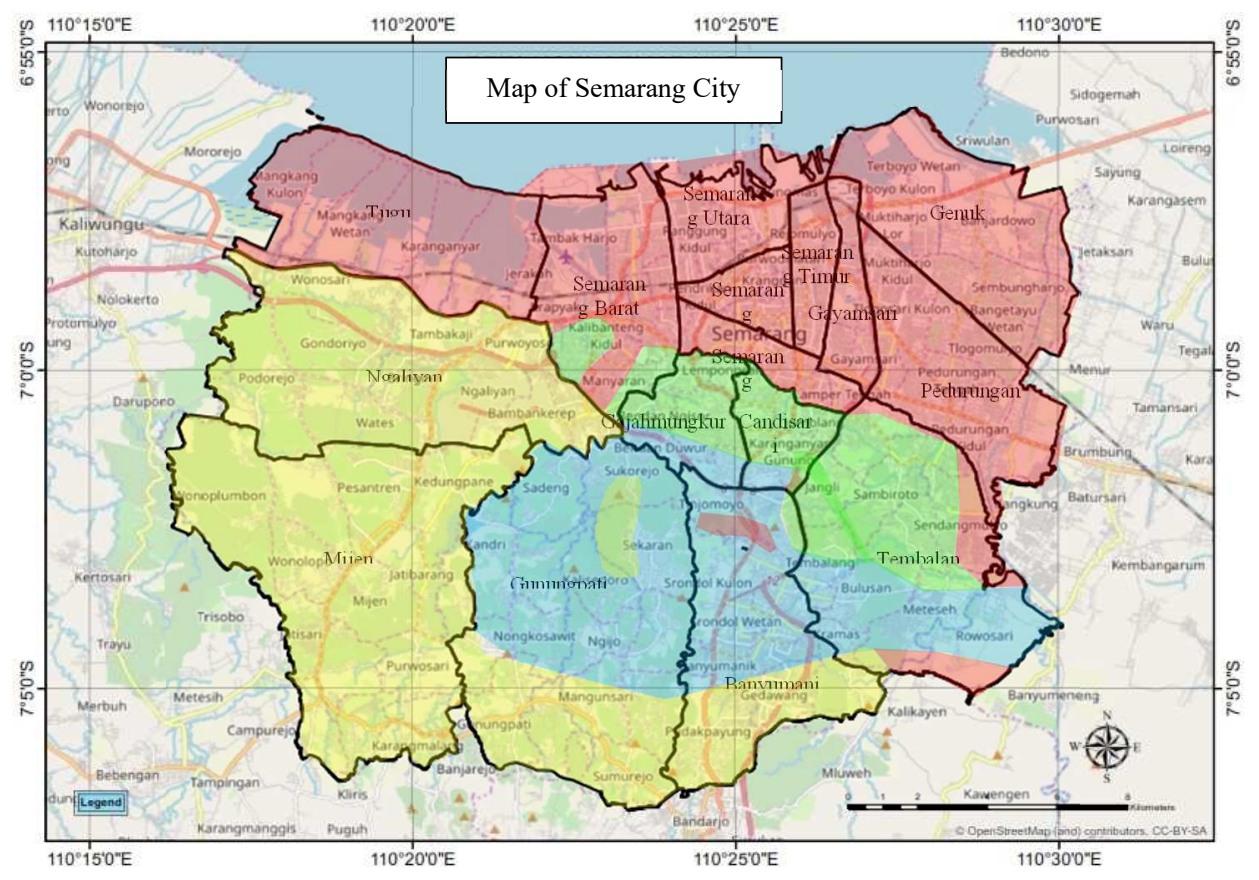


Table 6. Distribution of Land Bearing Capacity in Semarang City

\begin{tabular}{|c|c|c|c|c|}
\hline & Red Zone & Blue Zone & Yellow Zone & Green Zone \\
\hline District & $\begin{array}{l}\mathrm{BCL} \\
\left(\mathrm{kg} / \mathrm{cm}^{2}\right)\end{array}$ & $\begin{array}{l}\mathrm{BCL} \\
\left(\mathrm{kg} / \mathrm{cm}^{2}\right)\end{array}$ & $\begin{array}{l}\mathrm{BCL} \\
\left(\mathrm{kg} / \mathrm{cm}^{2}\right)\end{array}$ & $\begin{array}{l}\mathrm{BCL} \\
\left(\mathrm{kg} / \mathrm{cm}^{2}\right)\end{array}$ \\
\hline Gayamsari & $0.355-0.443$ & $\mathrm{X}$ & $\mathrm{X}$ & $\mathrm{X}$ \\
\hline Genuk & $0.089-0.443$ & $\mathrm{X}$ & $\mathrm{X}$ & $\mathrm{X}$ \\
\hline Pedurungan & $0.177-0.887$ & $\mathrm{X}$ & $\mathrm{X}$ & $\mathrm{X}$ \\
\hline $\begin{array}{l}\text { Semarang } \\
\text { Tengah }\end{array}$ & $0.089-0.532$ & $\mathrm{X}$ & $\mathrm{X}$ & $\mathrm{X}$ \\
\hline Semarang Timur & $0.044-0.887$ & $\mathrm{X}$ & $\mathrm{X}$ & $\mathrm{X}$ \\
\hline Semarang Utara & $0.000-0.133$ & $\mathrm{X}$ & $\mathrm{X}$ & $\mathrm{X}$ \\
\hline Banyumanik & $0.222-0.904$ & $0.904-2.035$ & $2.035-5.880$ & $5.880-10.640$ \\
\hline Candisari & $\mathrm{X}$ & $0.975-2.035$ & $\mathrm{X}$ & $5.880-11.083$ \\
\hline Gajahmungkur & $\mathrm{X}$ & $1.241-2.035$ & $\mathrm{X}$ & $5.880-11.083$ \\
\hline $\begin{array}{l}\text { Semarang } \\
\text { Selatan }\end{array}$ & $0.089-0.443$ & $\mathrm{X}$ & $\mathrm{X}$ & $\mathrm{X}$ \\
\hline Tembalang & $0.177-0.904$ & $0.904-2.035$ & $2.035-5.880$ & $5.880-10.640$ \\
\hline Gunungpati & $X$ & $0.975-2.035$ & $2.035-5.320$ & $\mathrm{X}$ \\
\hline Mijen & $\mathrm{X}$ & $\mathrm{X}$ & $3.547-4.433$ & $\mathrm{X}$ \\
\hline Ngaliyan & $\mathrm{X}$ & $\mathrm{X}$ & $3.325-4.433$ & $\mathrm{X}$ \\
\hline Semarang Barat & $0.089-0.904$ & $\mathrm{X}$ & $\mathrm{X}$ & $5.880-11.083$ \\
\hline Tugu & $0.089-0.177$ & $\mathrm{X}$ & $X$ & $X$ \\
\hline
\end{tabular}

\section{Conclusion}

a) From results of the study it can be concluded that parameters of soil engineering properties that determine the stability of bearing capacity of land in the city of Semarang are stratified:

very soft to soft/very loose has a bearing capacity of land $=<0.904 \mathrm{~kg} / \mathrm{cm}^{2}$, rather soft $/$ loose resistance has a bearing capacity of land $=0.904-2.035 \mathrm{~kg} / \mathrm{cm}^{2}$, rather hard to hard/rather dense has a bearing capacity of land $=2.035-5.880 \mathrm{~kg} / \mathrm{cm}^{2}$, very hard $/$ dense to very dense has a bearing capacity of land $=5.880->9.93 \mathrm{~kg} / \mathrm{cm}^{2}$.

b) Parameters distribution of soil engineering properties can describe bearing capacity of land in Semarang city which can be used as an instrument to determine bearing capacity of the environment and evaluation of spatial use from aspects of land use suitability and land capability.

c) Land loading exceeds bearing capacity of land will occur the failure of land stability in form of deformation / subsidence, collapse. 


\section{References}

[1] U. RI, "UU no.32 tahun 2009," UU no.32 tahun 2009, vol. 2, no. 5, p. 255, 2009.

[2] KementerianLH, "Permen LH No. 17 Tahun 2009," 2009.

[3] M. Irsam, "Land Subsidence dan Settlement di Semarang," 2018.

[4] Marsudi, "Prediksi Laju Amblesan Tanah di Dataran Aluvial Semarang Propinsi Jawa Tengah," Institut Teknologi Bandung, Bandung, 2001.

[5] A. M. Dwi Sarah, Eko Subowo, Rahmat Fajar Lubis, Dodit Murdohardono, "Identifikasi Faktor Geoteknik Penyebab Amblesan di Kota Semarang," 2011.

[6] P. K. Semarang, "Perda Kota Semarang no14 tahun 2011," pp. 10-14, 2011.

[7] B. P. S. K. Semarang, Kota Semarang Dalam Angka. Semarang: Badan Pusat Statistik Kota Semarang, 2017.

[8] T. W. Eko Subowo, Dwi Sarah, Dodit Mudoharjono, "Geologi Bawah Permukaan Wilayah Amblesan Tanah Kota Semarang," 2014.

[9] et al Thenden, Sumardirdja, "Peta Geologi Lembar Magelang dan Semarang, Jawa," 1996.

[10] M. S. WAHYUDI, Pribadi Agung; Ir. Suprapto T.M., "Hubungan Antara Sifat-sifat Tanah Dan Parameter Disain Tanah Dasar Badan Jalan Di Kodya Semarang," Universitas Gadjah Mada, 1997.

[11] A. D3441, "Standard Test Method for Mechanical Cone Penetration Tests of Soil," Astm D3441, 1998 .

[12] G. Sanglerat, "The Penetrometer and Soil Exploration," Soil Sci., 1973.

[13] T. W. Suyud W. U., Mudoharjono D., Pengertian, Ruang Lingkup Ekologi dan Ekosistem. Yogyakarta: Gadjahmada University Press, 2013.

[14] M. dan HAM, "Undang-undang RI no.26 tahun 2007 Tentang Penataan Ruang," no. 235, Jakarta: Pusat Hukum dan Humas, 2007, p. 245.

[15] L. D. Wesley, Mekanika Tanah, edisi I. Jakarta: Badan Penerbit Pekerjaan Umum, 1989.

[16] E. Bowles, Joseph, Sifat-sifat Fisis dan Geoteknis Tanah, 2nd ed. Jakarta: Erlangga, 1991.

[17] I. Subarkah, Teknik Pondasi Suatu Iktisar Praktis. Bandung: IDEA Dharma, 1979.

[18] G. Sanglerat, The Penetrometer And Soil Exploration. New York: Elsevier Publishing Company.

[19] A. Kezdi, "Physical properties of soils," Soil Mech. Found. Eng., 1968.

[20] A. Kezdi, "Handbook of soil mechanics. Volume 2: soil testing," Handb. soil Mech. Vol. 2 soil Test., 1979.

[21] G. Sanglerat, F. Bardot, and L. Girousse, "Settlement Predictions of Buildings Based on Static Penetrometer Data.," 1977. 